\title{
Pulverized Coal Injection (PCI) in a Blast Furnace*
}

\section{Introduction}

The use of coal as auxiliary fuel to replace a portion of coke in blast furnances is receiving increased attention on a world-wide basis. Kobe Steel, Ltd. has currently installed coal injection systems on its Kobe No. 3 BF (inner vol.: $1845 \mathrm{~m}^{3}$ ) and Kakogawa No. 2 BF (inner vol.: $3850 \mathrm{~m}^{3}$ ). They are now in operation since spring in 1983.

This paper summarizes the technical development of PCI system and the blast furnace performance in Kobe Steel, Ltd.

\section{Development of Technical Components}

Figure 1 is a flow diagram of PCI system at Kobe No. 3 BF.

It is essential to establish the following process subsystems and components, from coal receiving to the injection of pulverized coal (PG) at each tuyere, to fulfill the requirements for a commercial PCI operation:

1) Storage and discharge of raw coal

2) Pulverizing and drying of raw coal

3) Transportation, storage and supply of PG to the injection system

4) Uniform distribution of PG to each tuyere

5) Combusion of PC

6) Anti-explosion
Kobe Steel has established all the required process techniques.

Among these components, uniform distribution and combusion of $\mathrm{PC}$ are particularly important in maintaining stable operation of the blast furnace. For uniform distribution, the Petrocarb system (in U.S.A.) has been adopted because of its ease of flow-rate control at each individual tuyere, distribution accuracy, excellent economy and high reliability.

As for combustion, various necessary experiments have been conducted.

First of all, PG injection has been carried out in a single tuyere of Kobe No. 2 BF to determine optimum design conditions for the lance, blowpipe and other key items of equipment. Also at laboratories combustion furnace experiment and BF hot model experiment were performed under conditions similar to the blast furnace operation (except for pressure).

The time available for combustion is only milliseconds when injecting $P C$ because the volume for combustion in the blow-pipe, tuyere, and raceway is very small, and combustibility of $\mathrm{PC}$ is slightly less than heavy oil. Therefore, it is most important to increase combustion efficiency of coal.

Based on the results of combustion furnace experiment, Kobe Steel has developed the technology for improving combustibility by optimizing the injection conditions. At the same time, a simulation model, which can evaluate combustibility by the coal properties, has been established.

Lots of knowledge, obtained by the above mentioned experiments, have greatly contributed to the success of Kakogawa and Kobe PCI systems.

\section{Blast Furnace Performance}

PCI system at Kakogawa No. 2. BF started operation in March, 1983 and at Kobe No. 3 BF in May, 1983, respectively.

They have been operated under the stable conditions and PG rate of $50 \sim 55 \mathrm{~kg} / \mathrm{t}-\mathrm{HM}$ was achieved in Sept. 1983 (Table 1).

Operating results of the furnace for half a year have proven that PCI is effective to reduce the " inactive zone" at the wall which had been observed in all-coke operation. Kobe Steel is planning to increase $\mathrm{PC}$ rate up to $70 \mathrm{~kg} / \mathrm{t}-\mathrm{HM}$, and to inject coal with inferior properties.

\section{Summary}

As a result of the development work, pulverized coal could be easily prepared and injected into modern blast furnaces employing high-temperature blast.

The PCI technology thus developed will be applied to many fields as well as to the blast furnace.

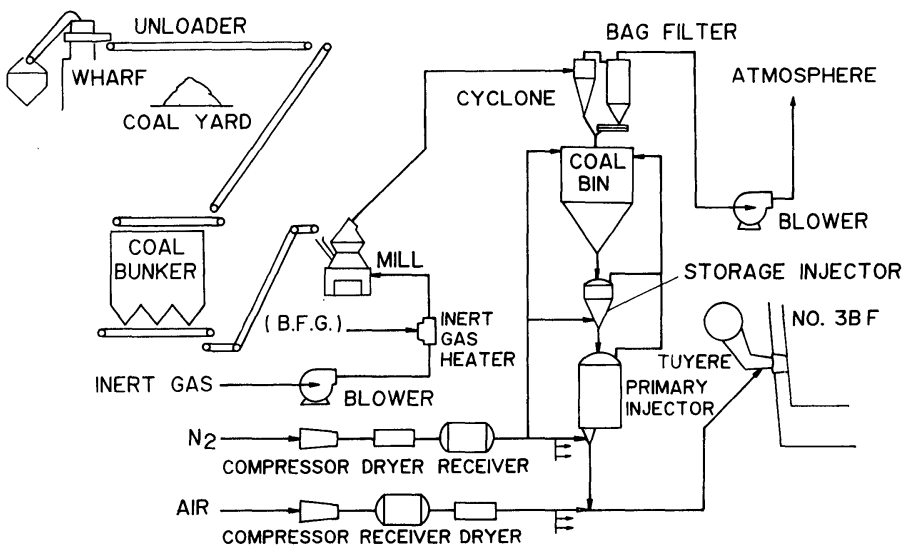

Fig. 1. Flow diagram of PGI system at Kobe No. 3 BF.

Table 1. Blast furnace campaign data (Aug., 1983).

\begin{tabular}{l|rr}
\multicolumn{1}{c|}{ Item } & $\begin{array}{c}\text { Kakogawa } \\
\text { No. 2 BF }\end{array}$ & $\begin{array}{c}\text { Kobe } \\
\text { No. 3 BF }\end{array}$ \\
\hline Production (t/d) & 7190 & 3751 \\
Productivity $\left(\mathrm{t} / \mathrm{d} / \mathrm{m}^{3}\right)$ & 1.87 & 2.03 \\
Coke rate $(\mathrm{kg} / \mathrm{t}-\mathrm{HM})$ & 455 & 432 \\
PG rate $(\mathrm{kg} / \mathrm{t}-\mathrm{HM})$ & 40 & 51 \\
Fuel rate $(\mathrm{kg} / \mathrm{t}-\mathrm{HM})$ & 495 & 483 \\
Blast temp. $\left({ }^{\circ} \mathrm{C}\right)$ & 1089 & 1199 \\
Blast moist. $\left(\mathrm{g} / \mathrm{Nm}^{3}\right)$ & 28 & 31 \\
Si in hot metal $(\%)$ & 0.32 & 0.36 \\
\hline
\end{tabular}

* For further information, write to Plant Planning \& Technical Department, Iron \& Steel Production Division, Kobe Steel, Ltd., 1-3-18 Wakinohama-cho, Chuo-ku, Kobe 651. (C) 1984 ISIJ 